\title{
NEW RECORDS OF SHRIMPS (DECAPODA: CARIDEA AND DENDROBRANCHIATA) IN DEEP WATERS OFF CHILE
}

\author{
NUEVOS REGISTROS DE CAMARONES (DECAPODA: \\ DENDROBRANCHIATA Y CARIDEA) ENAGUAS PROFUNDAS DE CHILE
}

\author{
Guillermo Guzmán ${ }^{1} \&$ Eduardo Quiroga² \\ ${ }^{1}$ Museo del Mar, Universidad Arturo Prat, Casilla 121, Iquique, Chile. Email: guillermo.guzman@unap.cl. \\ ${ }^{2}$ Programa Doctorado en Oceanografía, Universidad de Concepción, Casilla 160-C, Concepción, Chile. \\ Emailequiroga@udec.cl.
}

\begin{abstract}
Species of shrimps are revised based on bibliographic information and on specimens collected with an Agassiz trawl (AGT) during the PUCK-156 Expedition (2001) onboard R/V Sonne in three areas along Chilean coast; off Antofagasta (22 ${ }^{\circ}$ lat. S), off Concepción ( $36^{\circ}$ lat. S) and off Chiloé ( $42^{\circ}$ lat. S). 111 specimens belonging to 12 species were collected, including three new records for the Chilean fauna; Metacrangon procax, Nematocarcinus productus, and Merhyppolite sp. aff. M. america$n a$. Presence of Nematocarcinus lanceopes, Lebbeus antarcticus, Pandalopsis ampla and Sclerocrangon atrox in the collected material allows extension of their distributional ranges from sub-Antarctic to temperate areas.
\end{abstract}

KeYwords: Archibenthic shrimps, Dendobranchiata, Caridea, Chile.

\section{RESUMEN}

Se revisan las especies de camarones de aguas profundas, a partir de material bibliográfico y especímenes recolectados durante la expedición PUCK 156 (2001) a bordo del B/C Sonne en tres áreas de la costa de Chile: Antofagasta (22 ${ }^{\circ}$ lat. S), Concepción $\left(36^{\circ}\right.$ lat. S) y Chiloé $\left(42^{\circ}\right.$ lat. S). 111 especímenes correspondientes a 12 especies fueron reconocidos, incluyendo tres nuevos registros para la carcinofauna chilena; Metacrangon procax, Nematocarcinus productus y Merhyppolite sp. aff. M. americana. La presencia de Nematocarcinus lanceopes, Lebbeus antarcticus, Pandalopsis ampla y Sclerocrangon atrox en el material recolectado permite extender sus rangos de distribución desde áreas subAntárticas a temperadas de la costa de Chile.

Palabras Claves: Camarones archibentónicos, Dendobranchiata, Caridea, Chile.

\section{INTRODUCTION}

The Lund University Chile Expedition 1948-1949 (LUCE) (Brattström \& Johanssen 1983) was the most recent and important expedition realized in Chile, which included a broad latitudinal range and provide base information on decapod fauna to the date. Despite the advances to make inventory and complete the distribution ranges along Chilean coast, scarce information on deep-water shrimps in the literature is available, which also is restricted to few geographical locations (Retamal 1993, Retamal \& Soto 1995, Werthmann \& Carvacho 1997, Guzman 1999, Guzmán \& Wicksten 1998, 2000).
A total of 135 decapods shrimps species, belonging to Dendrobranchiata (ex Penaeoidea) and Caridea have been described, which include those reported at island areas, submarine mounts of Nazca and Salas y Gómez ridges, and those cited to circumantarctics waters (Retamal 1981, 1993, 1994, Wehrtmann \& Carvacho 1997, Guzmán \& Wicksten 1998, 2000, Guzmán 2002). These studies indicate that approximately $51 \%$ of decapod species correspond to pelagic and mesopelagic species, $29 \%$ to shallow-water species and $20 \%$ to benthodemersal shrimps (Guzmán, in prep). Recently, the number of new records has been increased, due to expeditions realized in Easter Island (Fransen 1987, Retamal 2001), the Nazca and Sala y 
Gómez ridges (Burukovsky 1990, Vereschaka 1990) and the Antarctic (Tiefenbacher 1991, 1994, Gorny 1999). However, oceanic zones remain under studied (Guzmán \& Rivera 2002), although new records to archibentic zone have been reported (Burukovsky 1990, Retamal 1993, Retamal \& Soto 1995, Guzmán \& Wicksten 2000,Zabala \& Bahamonde 1998).

This study updates and summarizes available information concerning to deep-water shrimps species ofChile through ofmaterial collected during the PUCK-156Expeditionalong the Chilean coast in 2001. This expedition considered three areas located between 22 to $42^{\circ}$ latitude south, off Chile. We also include information, description and figures concerning to new records of shrimp species that inhabiting deep-waters.

\section{MATERIALSANDMETHODS}

The material analyzed was collected in March and May 2001 during the PUCK-156 expedition on board RV Sonne at four stations (528-1775 m) offAntofagasta (22 ${ }^{\circ}$ lat. S), six stations (126-2225 m) off Concepción (36 lat. S) and six stations ( 160 - $1859 \mathrm{~m})$ off Chiloé $\left(42^{\circ}\right.$ lat. S) (Table I) by means of an Agassiz trawl (AGT) with a mouth width of
$1.5 \mathrm{~m}$ and $10 \mathrm{~mm}$ mesh. Adetail description of the sampling procedure has been presented by Arntz et al. (1999). Additionally, in each station hydrographical parameters (psu, $\mathrm{T}^{\circ} \mathrm{C}$ ) and dissolved oxygen were measured using a SEABIRD CTDO probe. The specimens from these samples were preserved in a solution of $10 \%$ formalin in filtered seawater with borax. Cephalotaracic length (l.c.) from all specimens was measured. The material was deposited in the Museo del Mar of the Arturo Prat University of Iquique, Chile.

Species identification was carried out using the following literature: Méndez(1981), Chace(1984, 1986), Burukovsky (1992), Holthuis(1993), Hanamura \& Evans(1996), Guzmán (1999), Guzmán \& Wicksten(1998,2000).

\section{RESULTS}

A total of 111 specimens belonging to 12 species were collected. Although decapod crustaceans were common within all three transect of investigations, shrimp species number varied between the areas. 53 specimens belonging to 8 species were registered at Chiloé. In contrast, 28 specimens belonging to 7 species were observed at Antofagasta (Table I).

TABLE 1. List of Agassiz tralw (AGT) stations, species number and number of individuals collected during PUCK-156 Expedition (Sonne 2001)

TABLA I. Lista de estaciones de muestreo con la rastra Agassiz (AGT), número de especies y número de individuos recolectados durante la expedición PUCK-156 (Sonne 2001).

\begin{tabular}{|c|c|c|c|c|c|c|}
\hline Station & Date & Latitude (S) & Longitude (W) & Depth (m) & No. species & No. individuals \\
\hline AGT-2 & 02-04-2001 & $22^{\circ} 51.99^{\prime}$ & $70^{\circ} 32.58^{\prime}$ & 891 & 1 & 1 \\
\hline AGT-4 & 03-04-2001 & $22^{\circ} 48.07^{\prime}$ & $70^{\circ} 42.29^{\prime}$ & 1775 & 3 & 23 \\
\hline AGT-5 & 04-04-2001 & $22^{\circ} 48.02^{\prime}$ & $70^{\circ} 36.71^{\prime}$ & 1351 & 2 & 3 \\
\hline AGT-6 & 04-04-2001 & $22^{\circ} 50.52^{\prime}$ & $70^{\circ} 30.95^{\prime}$ & 528 & 1 & 1 \\
\hline AGT-8 & 23-04-2001 & $36^{\circ} 02.35^{\prime}$ & $73^{\circ} 04.40^{\prime}$ & 365 & 1 & 25 \\
\hline AGT-9 & 23-04-2001 & $36^{\circ} 25.52^{\prime}$ & $73^{\circ} 23.36^{\prime}$ & 126 & 1 & 1 \\
\hline AGT-10 & 24-04-2001 & $36^{\circ} 32.54^{\prime}$ & $73^{\circ} 40.05^{\prime}$ & 867 & 1 & 1 \\
\hline AGT-11 & 24-04-2001 & $36^{\circ} 25.49^{\prime}$ & $73^{\circ} 35.72^{\prime}$ & 537 & 2 & 2 \\
\hline AGT-12 & $25-04-2001$ & $36^{\circ} 27.99^{\prime}$ & $73^{\circ} 46.47^{\prime}$ & 1424 & 2 & 3 \\
\hline AGT-14 & $30-04-2001$ & $42^{\circ} 24.56^{\prime}$ & $74^{\circ} 47.25^{\prime}$ & 276 & 2 & 15 \\
\hline AGT-18 & $02-05-2001$ & $42^{\circ} 35.35^{\prime}$ & $74^{\circ} 48.33^{\prime}$ & 507 & 5 & 37 \\
\hline AGT-19 & 03-05-2001 & $42^{\circ} 34.93^{\prime}$ & $74^{\circ} 50.25^{\prime}$ & 995 & 1 & 1 \\
\hline
\end{tabular}


DENDROBRANCHIATA

Haliporoides diomedeae (Faxon, 1893)

EXAMINED MATERIAL: 4 specimens, station AGT-2 (1.c. $=52.75 \mathrm{~mm})$, AGT-6 (1.c. $=28.75 \mathrm{~mm})$, AGT-11 $(1 . c .=11.40 \mathrm{~mm})$, and AGT-12 (1.c. $=52.55 \mathrm{~mm})$.

\section{CARIDEA}

Nematocarcinus lanceopes Bate, 1888

EXAMINED MATERIAL: 15 specimens, station AGT-18 (1.c. $=16.35 \pm 3.61 \mathrm{~mm})$

REMARKS: The present material extends the northern limit of the geographical distribution of this species from Barnevelt island $\left(55^{\circ}\right.$ lat S) (Arntz et al. 1999) to Chiloé $\left(42^{\circ}\right.$ lat. S). Five species belong to Nematocarcinus genus has been reported to Chilean waters, of these $N$. lanceopes and $N$. longirostris Bate, 1888 (cited to Chile as $N$. proximatus synonymized by Tiefenbacher, 1990) have a rostrum longer that overreach the antennal peduncle. This species have rostrum, which is projected beyond the antennal peduncle, and is armed with 25 to 35 dorsal spines, and 5 to 8 ventral spines (Tiefenbacher 1990).

Nematocarcinus sp. aff $N$. productus Bate, 1888

(Fig. 1a)

EXAMINED MATERIAL: 20 specimens, station AGT-4 (1.c. $=20.75 \pm 5.4 \mathrm{~mm})$.

REMARKs: Specimens are characterized by the presence of a rostrum longer than antennal peduncle, armed only dorsally with 14 to 27 spines, including those in the dorsal post orbital margin (Chace, 1986; Hanamura \& Evans, 1996). $N$. productus has been confused with $N$. longirostris $(=N$. proximatus), but the two can be separated by the rostrum, which is ventrally unarmed. The internae and masculinae appendix of males specimens revised here are similar to those reported for $N$. productus (Chace, 1986, page 2, figures $39 \mathrm{~g}$ and $\mathrm{r}$ ). $N$. productus is probably widely distributed in different oceans, but its distributional ranges "remain indeterminate" (sensu Chace, 1986). This represents the first record of the species in the southeastern Pacific Ocean off Chile (Antofagasta, 1775 m deep).

\section{Campylonotus semistriatus Bate, 1888}

EXAMINED MATERIAL: 2 specimens, station AGT-12 (1.c. $=26.2$ and $20.9 \mathrm{~mm}), 14$ specimens station AGT-14 (l.c. $=7.47 \pm 0.67 \mathrm{~mm}), 19$ specimens station AGT-18 (l.c. $=15.2 \pm 5.79 \mathrm{~mm})$.

\section{Acanthephyra pelagica (Risso, 1816)}

EXAMINED MATERIAL: 1 specimen, station AGT-18 (1.c. $=10.05 \mathrm{~mm})$

Merhippolyte sp. aff. M. americana Holthuis, 1961

(Fig. 1b)

EXAMINED MATERIAL: 1 ovigerous female, station AGT18 (1.c. $=16.1 \mathrm{~mm})$.

REMARKS: Our specimen is similar to $M$. americana Holthuis, 1961, but its morphology and meristic measured varied with respect to the original descriptions (Holthuis 1961), specially in the rostral spinations. Our specimen present eight dorsal and ten ventral spines (four to five dorsal, and five to seven ventral, in the original description in Holthuis,
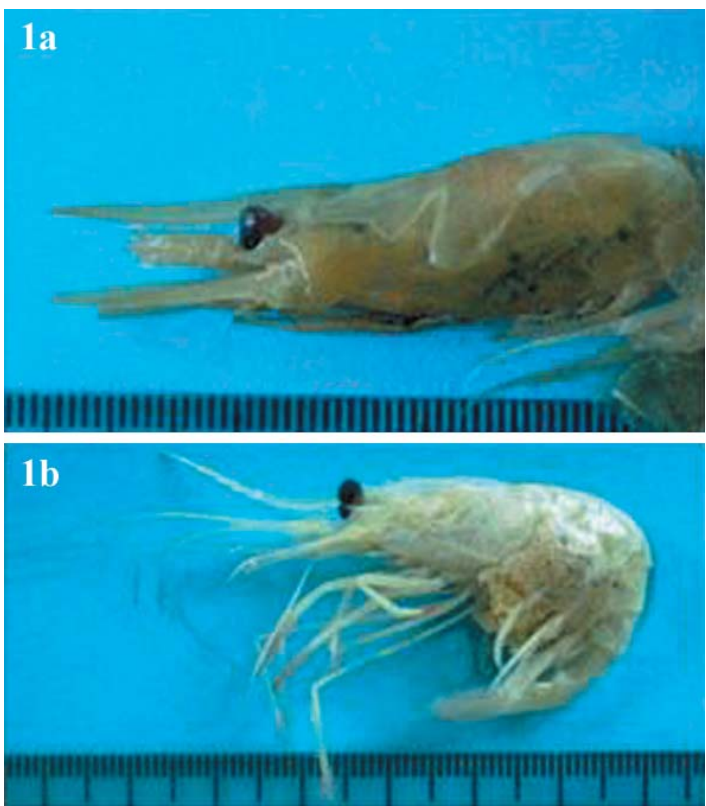

Figure 1. a) Lateral view of Nematocarcinus aff. $N$. productus, $20 \mathrm{~mm} \mathrm{l.c.} \mathrm{b)} \mathrm{Merhippolyte} \mathrm{aff.} \mathrm{M.} \mathrm{americana.}$ $10.05 \mathrm{~mm}$ l.c.

Figura 1. a) Vista lateral de Nematocarcinus aff. $N$. productus, $20 \mathrm{~mm}$ l.c. b) Merhippolyte aff. M. americana $10.05 \mathrm{~mm}$ l.c. 
1961 and Boschi et al. 1991); 16 carpal articles (13 to 14 carpal articles in the original description). Merus of third to fifth pereiopod with four strong external spines. These differences are not sufficient to assign to new species because hypolitids group of shrimps present a highly intra-specific variability (Wicksten, com. pers.). The specimens in the original Holthuis description (1961) were collected from shallow waters to $275 \mathrm{~m}$ deep. None species belong to this genus have been registered previously to Pacific waters.

\section{Lebbeus antarcticus Hale, 1976}

EXAMINED MATERIAL: 1 specimens, station AGT-4 $(1 . c .=19.00 \mathrm{~mm})$

REMARKS: The present material extends the northern limit of this species from southern areas of Chile (Gorny 1999) to Antofagasta $\left(22^{\circ} 48^{\prime} \mathrm{S}\right)$. This specie has been found in circum-Antarctic water masses to $2086 \mathrm{~m}$. Our specimen was registered to $1775 \mathrm{~m}$.

Heterocarpus reedi Bahamonde, 1955

EXAMINED MATERIAL: 25 specimens, station AGT-8 (14.35 mm avg. 1.c.; s.d.=3.72).

\section{Pandalopsis ampla Bate, 1888}

EXAMINED MATERIAL: one specimen, station AGT-10 $(1 . c .=19.50 \mathrm{~mm})$, and one specimen, station AGT15 (1.c. $=9.15 \mathrm{~mm})$.

REMARKs: Previously, this specie has been registered in deep waters of Antofagasta $\left(22^{\circ}\right.$ lat. S) (Zabala \& Bahamonde 1998) and Iquique (21 lat. S) (Guzmán, unpublished data). In the Pacific Oceans it has been previously registered from California Gulf, Mexico, Peru and Central Chile.

Pontophylus gracilis occidentalis Faxon, 1893

EXAMINED MATERIAL: 2 specimens, station AGT-4 (1.c. $=10.2$ and $13.4 \mathrm{~mm}$ ).

REMARKS: This genus are represented by six species (Chace, 1984), and six other subspecies are recognized (Chace, 1984). P. gracilis juncaeus Bate, 1888 (Burukovsky, 1990), and P. gracilis occidentalis Faxon, 1893 are cited to Southeastern Pacific (Retamal 1981, and Méndez 1981 as $P$. occidentalis). P. gracilis occidentalis can be separated by the presence of two spines in

the mid dorsal carine of carapace (sensu Chace, 1986).

Sclerocrangon atrox Faxon, 1893

(Fig. 2a)

EXAMINED MATERIAL: 1 specimen, station AGT-19 (1.c. $=42.00 \mathrm{~mm}$ ); 2 specimens, station AGT-05 (1.c. $=$ 38.40 and $29.25 \mathrm{~mm}$ ).

Remarks: This specie is distributed from Mexico to Peru (Méndez, 1981). The present material extends the northern limit of this species from Magellan Straits $\left(56^{\circ}\right.$ lat. S.) (Bahamonde 1981) to Antofagasta $\left(22^{\circ}\right.$ lat. S), Chile.

\section{Metacrangon procax (Faxon, 1893)}

(Fig. 2b)

EXAMINED MATERIAL: 1 specimen, station AGT-5 (1.c. $=14.00 \mathrm{~mm}$ ); 1 specimen, station AGT-18 (1.c. $=$ $14.95 \mathrm{~mm})$.

REMARKS: Specimens are similar to M. agassizi (Smith 1882), in the Atlantic Ocean, but the two species can be separated by the angle of rostrum, the length of first spine in the dorsal carina, and the length of the lateral spines (Faxon 1893; Smith 1882). This represents the first record of the species in the southeastern Pacific Ocean off Chile (Antofagasta, Chiloé).

\section{DISCUSSION}

Three new records for the Chilean fauna; Metacrangon procax, Nematocarcinus productus, and Merhyppolite sp. aff. M. americana are reported. It is know that the number of species recorded from Chilean waters has increased in the recent years due to increased in the surveys (Guzmán \& Rivera 2002). Including those records together with reported in this study, the number of species described from Chilean waters increased to 138 species. Relatively few species reported from Chile, occur in the subantarctic regions (Werthmann \& Carvacho 1997). However, the presence of Nematocarcinus lanceopes, Lebbeus antarcticus, Pandalopsis ampla and Sclerocrangon atrox in the collected material allows its extension of their distributional ranges from subAntarctic to temperate areas. 

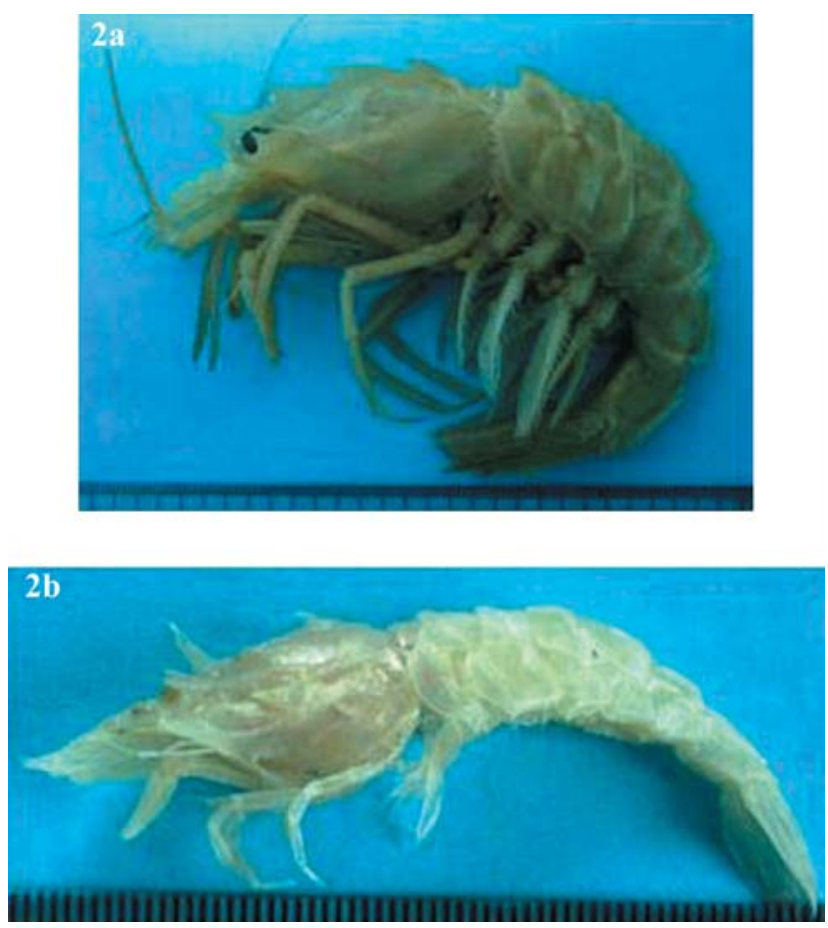

FiguRE 2. a) Lateral view of Sclerocrangon atrox, $42.00 \mathrm{~mm}$ l.c., b) Metacrangon procax, $14.00 \mathrm{~mm}$ 1.c.

FIgURA 2. a) Vista lateral de Sclerocrangon atrox, $42.00 \mathrm{~mm}$ 1.c., b) Metacrangon procax, $14.00 \mathrm{~mm}$ 1.c.

\section{AKNOWLEDGMENTS}

We would like to thank to the Alfred-WegenerInstitut for Polar and Marine Research, University of Bremen and Department of Oceanography, University of Concepción, especially to Prof. Dr. W. Arntz, Prof. Dr. V. A. Gallardo, Dr. D. Gerdes and Dr. Dierk Hebbeln. This study was supported by the Centre for Oceanographic Research in the Eastern South Pacific (COPAS). The expedition was funded by the German BMBF (No. 03G0156A). Ongoing cooperation between the AWI and UDEC was funded by the International Bureau of the BMBF (proyect number CHL01/010) and the International Program of Scientitific Cooperation (CONICYT) in Chile.

\section{BIBLIOGRAPHY}

Arntz, W. E., M. Gorny, R. Soto, M.A. Lardies, M. A. Retamal \& I. S. Wehrtmann. 1999. Species composition and distribution of decapod crustaceans in the waters off Patagonia and Tierra del Fuego, South America. Scientia Marina 63 (Supl. 1): 303-314.

BAHAMONDE, N. 1981. Adiciones a la fauna carcinológica de Chile: Sclerocrangon atrox Faxon, 1893. Noticiario Mensual del Museo Nacional de Historia Natural Santiago. 296: 3-6.

Boschi, E. E., C. E. Fischiach \& M. I. Iorio. 1991. Catálogo ilustrado de los crustáceos estomatópodos y decápodos marinos de Argentina. Frente Marítimo 10 A: 7-94.

Brattstrom, H. \& A. Johanssen. 1983. Ecological and regional zoogeography of the marine benthic fauna of Chile. Sarsia 68: 289-339.

Burukovsky, R. N. 1990. Shrimps from the Salas y Gómez and Nazca Ridges. Trudy Instituta Okeanologii AN USSR, 124: 187-217.

Burukovsky, R. N. 1992. Key to shrimps and lobster. Russian Traslation Series, Vol. 5 A.A. Balkema (Ed.). Rotterdam: 1-174.

Chace, F. A. 1984. The Caridean shrimps (Crustacea: Decapoda) of the Albatross Philippine Expeditions, 1907-1910, Part 2. Families Glyphocrangonidae and Crangonidae. Smithsonian Contributions to Zoology 397: $1-63$. 
Gayana 69(2), 2005

Chace, F. A. 1986. The Caridean shrimps (Crustacea: Decapoda) of the Albatross Philippine Expeditions, 1907-1910, Part 4. Families Oplophoridae and Nematocarcinidae. Smithsonian Contributions to Zoology 432: 1-82.

FAXON, W. 1893. Reports of the dredging operations off the west coast of central America to the Galapagos, to the west coast of Mexico and in the Gulf of California, in charge of Commander Z. L. Tanner, U. S. N. commanding. VI Preliminary descriptions of new species of Crustacea. Bulletin Museum of Comparative Zoology at Harvard College 24 (7): 1220

Fransen, C. H. 1987. Notes on Caridean shrimps of Easter Island with description of three new species. Zoologische Mededelingen 61 (35): 501-531.

GoRnY, M. 1999. On the biogeography and ecology of the Southern Ocean decapod fauna. Scientia Marina 63 (Supl. 1): 367-382.

GuZMÁn, G. 1999. Nuevos registros de camarones sergéstidos (Crustacea; Decapoda; Dendrobran-chiata) en el norte de Chile. Investigaciones Marinas, Valparaíso, 27: 87-91.

Guzmán, G. 2002. Mesopelagic shrimps of the family Sergestidae (Decapoda; Dendrobranchiata) new records for the Southeastern Pacific. Crustaceana, 75(9): 133-146.

Guzmán, G. \& J. Rivera. 2002. Stylopandalus richardi (Coutiere 1905) primer registro para aguas del Pacífico sur este (Decapoda, Pandalidae). Investigaciones Marinas, Valparaíso, 30(1): 67-70.

Guzmán, G. \& M. K. Wicksten. 1998. Nuevos registros de camarones de la familia Pasiphaeidae (Crustacea, Decapoda) en el norte de Chile $\left(18^{\circ}\right.$ a $22^{\circ}$ lat Sur, $70^{\circ}$ a $72^{\circ}$ long W). Gayana Zoología 62 (2): 203210.

Guzmán, G. \& M. K. Wicksten. 2000. The subfamily Benthesicyminae Bouvier, 1908 (Decapoda, Dendrobranchiata) in the northern zone of Chile $\left(18^{\circ}\right.$ a $22^{\circ}$ S). Crustaceana 73(8): 925-931.

Hanamura, Y. \& D. R. Evans. 1996. Deepwater Caridean shrimps of the Families Nematocarcinidae, Stylodactylide, Pandalidae and Crangonidae (Crustacea: Decapoda) from Western Australia Bulletin of Nansei National Fisheries Research Institute 29: 1-18.

Holthuis, L. B. 1961. A new species of Merhyppolyte (Decapoda, Natantia) from East American waters. Crustaceana 2: 1-5.

Holthuis, L. B. 1993. The recent genera of the caridean and stenopodidean shrimps (Crustacea, Decapoda). With an appendix on the order Amphionidacea. Nationaal Natuurhistorisch Museum, III edition: 1-328.

MÉNDEZ, M. A. 1981. Claves de identificación y distribución de los langostinos y camarones (Crustacea: Decapoda) del mar y ríos de la costa del Perú. Boletín Instituto del Mar del Perú, 5: 1-170.

Retamal, M. A. 1981. Catálogo ilustrado de los crustáceos decápodos de Chile. Gayana Zoología 44: 1-110.

Retamal, M. A. 1993. Crustáceos decápodos abisales de la zona Iquique - Arica. Estudios Oceanológicos 12: $1-8$

Retamal, M. A. \& R. Soto. 1995. Primer registro de Psathyrocaris fragilis Wood-Mason, 1893 en aguas chilenas (Decapoda - Pasiphaeidae). Gayana Zoología 59 (2): 117-118.

SMITH, S. 1882. Reports on the results of dredging, under the supervision of Alexander Agassiz, on the East Coast of the United States, during the summer of 1880, by the U.S. coast steamer "Blake", commander J. R. Barlett, U. S. N., commanding. Report on the Crustacea. Part I. Decapoda. Bulletin of the Museum of Compartative Zoology at Harvard College 10 (1): 1-108. plt 1-16.

TIEFENBACHER, vON L. 1990. Beitrage zur taxonomie von Nematocarcinus longirostris Bate, 1888 und Nematocarcinus lanceopes Bate, 1888, neu fur die westliche Antarktis. Spixiana 13 (3): 229-235.

TIEFEnBACHER, vON L. 1991. Ammerkungen zu einigen mesopelagischen Gernelen und ihrer Verbreitung in den Gewässern der westkichen Antarktis. Spixiana 14 (2): 153-158.

Tiefenbacher, von. 1994. Decapode /crustaceen aus westantarktischen Gewassern gesammelt von der R.V. "John Biscoe", Reise 11. Spixiana 17 (1):1319.

VereschaKa, A. L. 1990. Pelagic decapods from seamount of Naska and Sala y Gomez ridges. In: A. N. Miranov y J. A. Rudjakov (eds.), Plankton and benthos from the Nazca and Sala y Gomez submarine ridges. Trudy Instituta Okeanologii AN USSR, 124: 129 - 155

Wehrtmann, I. \& A. Carvacho. 1997. New records and distribution ranges of shrimps (Crustacea: Decapoda: Penaeoidea and Caridea) in Chilean waters. Proceedings of the Biological Society of Washington 110 (1): 49 - 57.

Zabala, P. \& N. Bahamonde. 1998. Pandalopsis cf ampla Bate, 1888 frente a Antofagasta, Chile (Crustacea, Decapoda, Caridea, Pandalidae). Noticiario Mensual del Museo Nacional de Historia Natural Santiago, 332: $17-22$.

Fecha de recepción: 26/05/04

Fecha de aceptación: 12/08/05 